\title{
Postharvest Quality of Cut Roses With the Application of Salicylic Acid
}

\author{
Sérgio Miguel Mazaro ${ }^{1}$, Edson Bertoldo ${ }^{2}$, Nean Locatelli Dalacosta ${ }^{2}$, Fabiana Chiamulera Borsatti ${ }^{2}$, \\ Mycheli Preuss da Cruz ${ }^{1}$, Américo Wagner Júnior ${ }^{1} \&$ Jucelaine Haas $^{1}$ \\ ${ }^{1}$ Federal Technological University of Paraná, Campus Dois Vizinhos, PR, Brazil \\ ${ }^{2}$ Federal Technological University of Paraná, Campus Pato Branco, PR, Brazil \\ Correspondence: Sergio Miguel Mzaro, Federal Technological University of Paraná, Campus Dois Vizinhos, \\ Km 04, CEP 85660-000, Dois Vizinhos, PR, Brazil. Tel: 55-(46)-3536-8900. E-mail: sergio@utfpr.edu.br
}

Received: March 11, 2018

Accepted: May 27, $2018 \quad$ Online Published: July 15, 2018

doi:10.5539/jas.v10n8p397

URL: https://doi.org/10.5539/jas.v10n8p397

\begin{abstract}
The objective of this work was to evaluate the effect of the application of salicylic acid (SA) on the maintenance of quality and longevity of cut roses cv. Vega. Cut roses were kept in a vase solution of SA and water at concentrations of $0 ; 0.5 ; 1.0 ; 1.5$ and $2.0 \mathrm{mM}$. All treatments were kept at $8 \pm 2{ }^{\circ} \mathrm{C}$ for 96 hours, simulating storage in flower shops; the flowers were then evaluated regarding loss of fresh matter and leaf chlorophyll content and were transferred to beakers containing distilled water at $25 \pm 2{ }^{\circ} \mathrm{C}$ for more 144 hours, simulating shelf life. At $24,48,72$ and 96 hours from the beginning of the experiment, biochemical analyses of total proteins and the activity of the phenylalanine ammonia-lyase (PAL) and peroxidases (PO) were performed. Visual analyses were performed (stem curvature, turgescence and petal darkening) every 48 hour intervals until the end of the experiment. The treatments with SA allowed the maintenance of post-harvest quality, reducing the loss of fresh matter mass, lower stem curvature, greater turgescence and less darkening of the petals. The results showed that the application of SA increased total protein contents and FAL, which characterizes the activation of plant defense mechanisms to the senescence process.
\end{abstract}

Keywords: flower, flowering stem, Rosa sp., senescence

\section{Introduction}

The market for flowers and ornamental plants is expanding, being considered one of the most promising sectors of agribusiness. Roses are one of the most commercialized species, especially as cut flowers. However, cut flowers have a reduced shelf life due to their intense post-harvest catabolic reactions, leading to rapid deterioration (Hardenburg, Watada, \& Wang, 1988). Cut flowers are sensitive to microbial contamination at the stem base or in the vase solution, consequently were caused to shortening their vase life (Balestra et al., 2005).

Alternative methods to extend shelf life are being tested, such as refrigeration and maintenance of cut flowers in solution, also known as vase solutions. The latter contain substances which may be used singly or in combination to retard the senescence of the cut flowers.

Salicylic acid (SA) is a natural compound that reduces the damage caused by ethylene during plant senescence (Geerdink, 2012), acting as an endogenous signalling molecule. The exogenous SA, when applied, induces the production of its precursor of methyl salicylate (Resende, Salgado, \& Chaves, 2003), increasing the synthesis of SA in plant tissues, phenylalanine ammonia-lyase (PAL) and the production of proteins related to pathogenesis (PR-proteins) (Spletzer \& Enyedi, 1999), inhibiting the synthesis of ethylene (Raskin, 1992). SA can prevent ACC-oxidase activity and decrease ROS (Reactive Oxygen Species) with increasing antioxidant enzyme activity (Canakci, 2008; Kalidage et al., 2009).

During evolution, plants developed defence mechanisms activated only in response to pathogen infection or treatment with certain biological or synthetic chemicals, called elicitors (Cavalcanti, Piero, Cia, Paschoalati, \& Resende, 2005). This defence activation is called systemic acquired resistance (SAR), and it is characterised by the production of a signal from the infection site, causing necrosis and translocation of this signal to other parts of the plant, inducing defence reactions that will protect the plant against future aggression (Da Silva, Reis, Baldani, \& Olivares, 2008). According to Leon-Kloosterziel et al. (2005) there are several enzymes related to induced 
resistance, such as peroxidases, poliphenol oxidases, PAL, $\beta$-1,3-glucanases and chitinases. When the plant is lead to induction, the activity of these enzymes in the area tends to increase when compared to plant tissues not exposed to the elicitors (Bettiol \& Morandi, 2009).

Several papers discourse on SA role in fruit shelf life (Rossarolla, 2012; Campos et al., 2004; Zhang, Chen, \& Ferguson, 2003), and in flower preservation (Zamani, Kazemi, \& Aran, 2011; Shakib, Naderib, \& Boojarc, 2012), specially roses (Geerdink, 2012). Published research it has been found that SA delayed Gladiolus flower senescence (Ezhilmathi et al., 2007).

Nonetheless, we did not find any published research regarding the effect of different concentrations of exogenous SA in similar conditions of floriculture storage (refrigeration and vase preservation until commercialisation).

Thus, the objective of this work was to evaluate the effect of exogenous SA on quality maintenance and longevity of cut roses.

\section{Material and Methods}

Pink closed rose buds (Rosa sp.) cv. Vega from the Veiling in Holambra, of the commercial production of Holambra, São Paulo, Brazil, were maintained and transported under refrigeration to the Phytopathology Lab at the Federal University of Technology-Parana, campus Dois Vizinhos. Rose stems free from visible wounds or disease symptoms were selected and were trimmed to $40 \mathrm{~cm}$-length using cutters. The cut roses were maintained at $8 \pm 2{ }^{\circ} \mathrm{C}$ in the first 96 hours simulating floriculture storage; and later, at $25 \pm 2{ }^{\circ} \mathrm{C}$ for 144 hours, simulating shelf life The total duration of the experiment was 240 hours.

The stems were placed randomly in beakers containing $500 \mathrm{~mL}$ of SA solution at concentrations of $0 ; 0.5 ; 1.0 ; 1.5$ and $2.0 \mathrm{mM}(\mathrm{w} / \mathrm{v})$ in distilled water for 96 hours. At 24, 48, 72 and 96 hours, standard $10 \mathrm{~mm}$ discs were collected from rose petals and frozen in liquid nitrogen and kept in a freezer at $-20{ }^{\circ} \mathrm{C}$. The material was used for biochemical analysis of total protein contents and enzymatic activity of Phenylalanine ammonia lyase (PAL) and Peroxidases (PO).

Protein contents were determined using the test proposed by Bradford (1976), with 0.2 Molar phosphate buffer 0.2 M pH 7.5 and reagent Bio-Rad ${ }^{\circledR}$. Readings were performed with spectrophotometer $(630 \mathrm{~nm})$; bovine serum albumin was the standard. PAL determination was performed by colorimetric quantification of trans-cinnamic acid from phenylalanine, according to Kuhn (2007). PO extraction and activity determination were done according to Matsuno and Uritani (1972).

At 96 hours, the cut roses were removed from the solution. The stem leaves were used to determine the Falker Chlorophyll Index (FCI) using the equipment ClorofiLOG ${ }^{\circledR}$ model CFL1030, which gives values proportional to the absorbance of chlorophyll $a, b$ and $t(a+b)$, presenting high correlation index with values obtained by direct methods (Falker Automação Agrícola Ltda., 2008).

Also, loss of fresh matter in each experimental unit was evaluated, obtained by the difference of fresh weight of the roses at the beginning of the experiment and weight at 96 hours, expressed as percentage. These evaluations were performed in the first 96 hours considering this period would be sufficient for SA activation and metabolic response. In addition, this is the maximum time roses are stored in flower shops, since they are replaced every four days - according to roses distributors. The stems were then placed in beakers containing distilled water until the end of evaluations.

Visual analysis of neck bending, turgescence and darkening of the petals was performed every 48 hours since the stems were placed in the SA solution until the end of the experiment, totalising 10 days or 240 hours-considering that the cut roses can last up to six days after being acquired from customers in flower shops All roses were analysed in the experimental unit, evaluating neck bending (grading notes: $1:>90^{\circ}, 2: \leq 45^{\circ}$ and 3 : straight stem), turgescence (1: wilted, 2: slightly wilted and 3: turgid) and coloration of the petals (1: dark, 2: slightly dark and 3: without darkening), according to the methodology proposed by Geerdink (2012).

The experiment was conducted in a completely randomized design, with four replications and eight floral stems per experimental unit.

The collected data were submitted to analysis of variance $(p \leq 0.05)$ and presented as descriptive statistics (mean \pm standard deviation) and regression analysis $(p \leq 0.05)$ by the Assistat ${ }^{\circledR}$ program (Silva \& Azevedo, 2009).

\section{Results and Discussion}

Chlorophylls are the most abundant natural pigments in plants. They occur inside chloroplasts in leaves and other plant tissues, converting luminous energy into chemical energy (Elbe, 2000). These pigments are fundamental to maintain the visual and commercially desired characteristics in post-harvest. 
According to Q. Hayat, S. Hayat, Irfan, and Ahmad (2010), SA participates in the regulation of several physiological processes, such as photosynthesis. In this work, it was possible to observe that SA concentrations did not interfere significantly on FCI for $a, b$ and $t$ chlorophyll. Hayat, Fariduddin, Ali, and Ahmad (2005) found that pigment contents increased significantly in wheat seedlings when it was applied SA in concentrations lower than $0.01 \mathrm{mM}$, while higher concentrations did not lead to a beneficial effect. A hypothesis for our results is that the concentrations that we used were not high enough to cause alterations on the FCI, which also varies with the plant species.

The loss of fresh mass had linear effect with the concentrations of SA in the evaluation done at 96 hours after the start of the experiment, that is, with the increase of the concentração, there was a reduction of fresh mass losses (Figure 1). The same result was found by Geerdink (2012) working with SA and other resistance elicitors in cut roses. Since SA is an ethylene antagonist (Cia, Pascholati, \& Benato, 2007), there may have been a reduction in the primary metabolism, such as respiration and transpiration, with consequent lower water loss, leading to a reduction in the mass loss of roses by treatment.

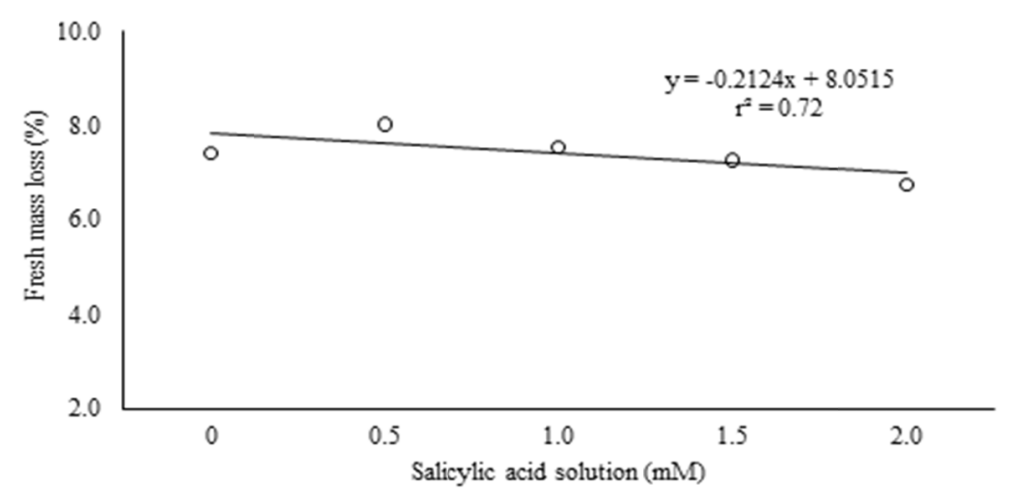

Figure 1. Fresh mass loss of rose stems according to the concentration of salicylic acid after 96 hours of your application $(p \leq 0.05)$. UTFPR, Dois Vizinhos-PR, 2013

The results showed that there was variation in the protein content a function of the SA concentration and the evaluation times (Figure 2A), except control, which was stable until the end of storage (96 hours). In all concentrations there was an increase of the protein content in the first 24 hours, in the following evaluations, the concentration $0.5 \mathrm{mM}$ reduced the protein contents, for the others, the increase of the protein contents was maintained as a function of time. In the highest concentrations, the peak activity occurred at 48 to $2.0 \mathrm{mM}$ and 96 hours at $1.5 \mathrm{mM}$, while in the lower it occurred as early as 24 hours. 

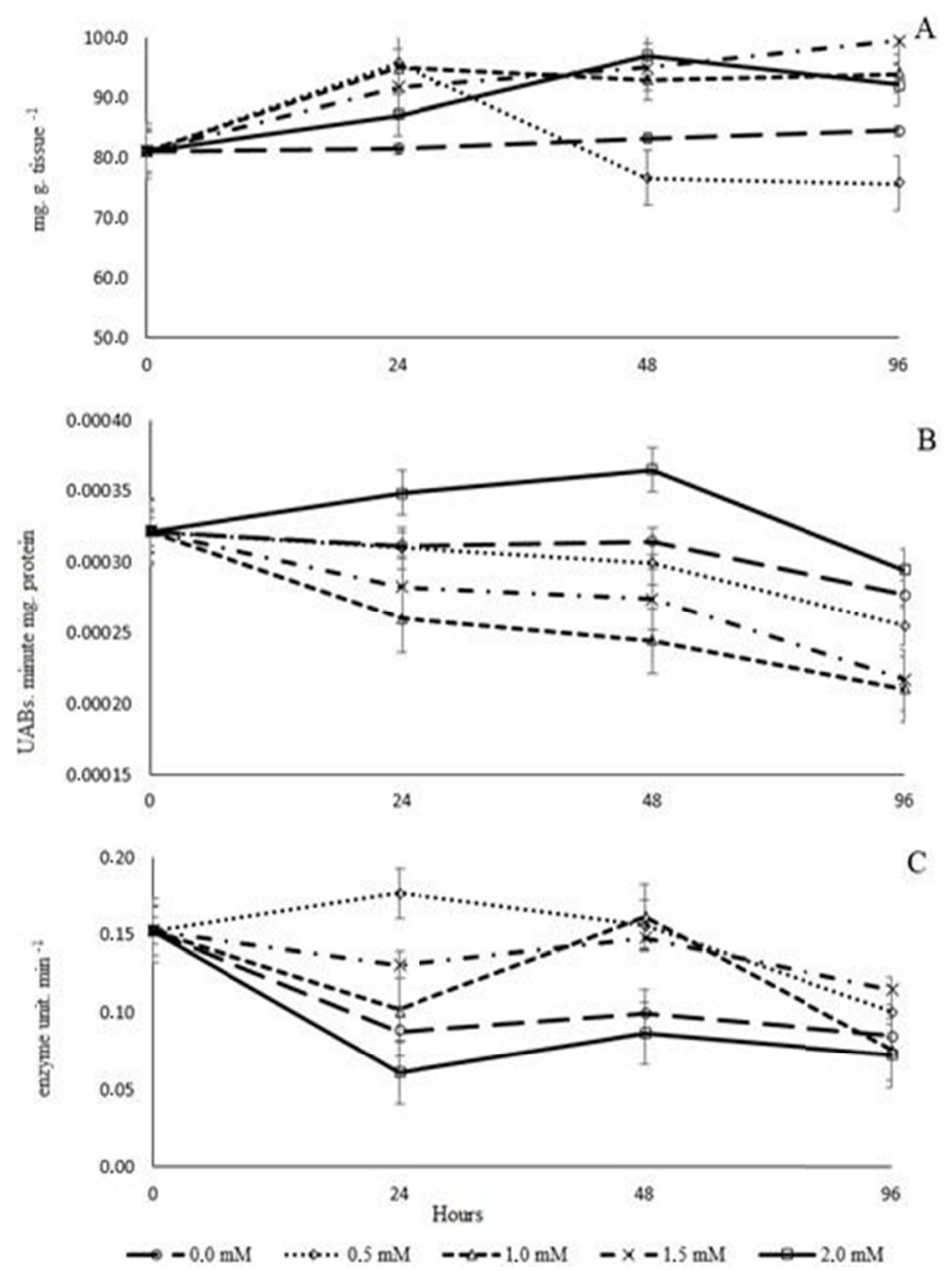

Figure 2. Protein content (A), PAL (B) and peroxidase activity (C) of cut roses evaluated at $0,24,48$ and 96 hours after application of salicylic acid solution in five concentrations $(0,0.5,1.0,1.5$ and $2.0 \mathrm{mM})$. Vertical bars indicate the standard deviation. UTFPR, Dois Vizinhos-PR, 2013

The increase in protein content caused by SA may be related to the activation of pathogenesis related proteins (PR-proteins), involved in the defense of the plant. The data from this work corroborate with Spletzer and Enyedi (1999), who described that exogenous SA can induce PR proteins, allowing the protection of plants against pathogens, increasing the shelf-life of cut roses.

The treated roses with the highest concentration of SA $(2.0 \mathrm{mM})$ presented higher activity of PAL (Figure 2B) in all the evaluated periods, when compared to the others and the control. The peak activity occurred at 48 hours, with a decrease in the following evaluation ( 96 hours). The other concentrations obtained smaller activities than the control (Figure 2B).

Campos et al. (2003), evaluating the chalcone synthase and PAL of four common bean cultivars, verified increased activity when the plants were treated with SA and fungi as elicitors, significant differences with the control occurred after three days after treatment. Chen et al. (2006) also observed that SA-treated grapes had PAL activated.

This increase in the activity of PAL can be associated with the recognition of SA in the plant, which triggered an increase in the synthesis of the SA itself, being synthesized in the path of the phenylpropanoids that have their precursors formed by the enzymatic action of PAL (Da Silva et al., 2008).

For the PO activity (Figure $2 \mathrm{C}$ ), the control and SA $(2.0 \mathrm{mM})$ had the lowest values when compared to other concentrations $(0.5,1.0$, and $1.5 \mathrm{mM})$ at all evaluations. This variation as a function of the concentrations of SA should be further studied, since it is directly linked to tissue lignification, which polymerizes lignin from hydroxyl 
oxidation of phenolic groups (Pascholati \& Leite, 1995; Castro, Kluge, \& Peres, 2005), makes it important for the defense and sustainability of the plant.

The low activity of detoxifying enzymes, such as peroxides, may be indicative of tissue aging (M. I. F. Chitarra \& A. B. Chitarra, 2006). This fact coincides with the reduction of the visual parameters of stem curvature, turgescence and darkening of the petals (Figure 3), suggesting an aging of the tissues, although the application of SA has reduced this effect.

In Figure 3, it is possible to verify that there were no changes in relation to the stem curvature, turgescence and stem darkening up to 48 hours of experiment installation. The treated petals of roses with higher concentration of SA $(2.0 \mathrm{mM})$ always maintained the highest scores for all parameters, thus maintaining the quality of the roses throughout the evaluation period. Results that corroborate with those found by Geerdink (2012), who worked with the application of SA in cut roses.

For the stem curvature (Figure 3A), concentrations of 1.5 and $2.0 \mathrm{mM}$ maintained the flowers with note 2 for a longer time (192 hours) after treatments, different from the others, which obtained smaller notes in the same period. For the turgescence and darkening of petals (Figures $3 \mathrm{~B}$ and $3 \mathrm{C}$ ), the results were similar to those obtained with the curvature of the stem, presenting darker and darker petals up to 144 and 192 hours after treatments. All treatments showed a marked decrease after 240 hours of application, with scores close to 1 .
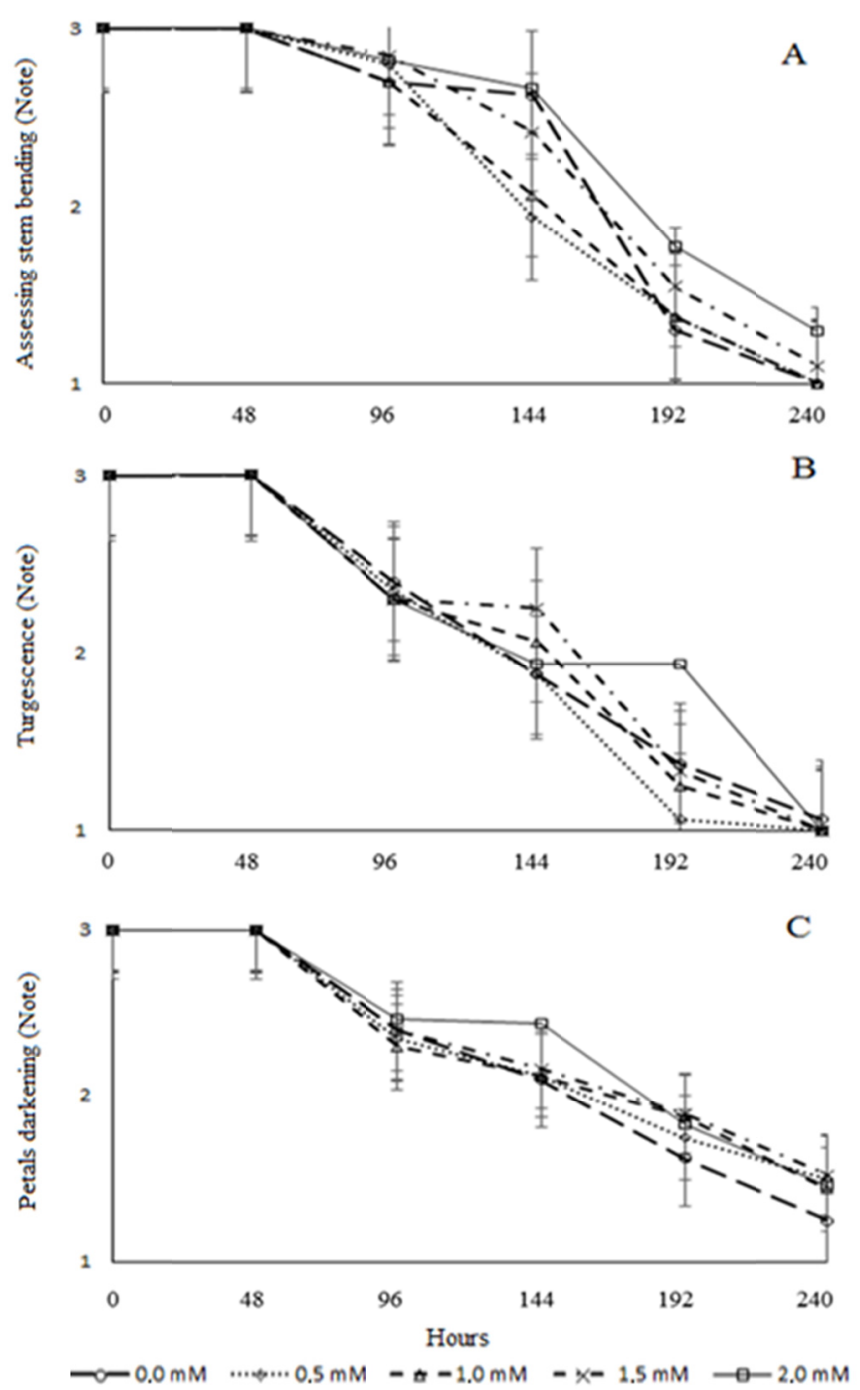

Figure 3. Qualitative characteristics of stem bending (A), turgescence (B) and petals darkening of rose (C) 'Vega' treated with solution containing five different concentrations of salicylic acid. Vertical bars represent the mean standard deviation. UTFPR, Dois Vizinhos, 2013 
These qualitative characteristics found in the present work are probably related to the lower mass loss of fresh matter (Figure 1), since the stems treated with the highest concentrations of AS were the ones that obtained the lowest loss in relation to the others during the experiment. It is assumed that those that were longer turgid presented lower stem curvature and darkening of petals, since according to Cortes et al. (2011), working with 'Grand Gala' rose stems, state that high levels of tissue hydration are generally associated with increased vase life of cut flowers.

This is corroborated by Geerdink (2012) who claims that qualitative characteristics are linked to the water balance of floral stems, since it is an important part for maintaining the cellular structures and consequently for visual appearance, since turgid petals become brighter, and thus more attractive to the consumer.

The goal is to maintain the quality of the roses, our service network, turgescence and obscuration of the petals, give by inhibition of post-harvest metabolism, respiratory or ethylene synthesis. As is the ethylene antagonist (Raskin, 1992), it is likely that inhibition of biosynthesis and ethylene action is suggested, which allows better roses when treated with AS.

Research to complement these results, referring to respiratory metabolic behavior with quantification of $\mathrm{CO}_{2}$ and $\mathrm{O}_{2}$ levels and ethylene production should be performed, since our collected data show that SA is promising for quality maintenance post-restoration of cut roses.

\section{Conclusion}

The different concentrations of SA did not interfere on the FCI in this experiment. Treatments with SA provided better quality cut roses in post-harvest, with reduced mass loss, neck bending, wilting and petal darkening. The application of SA also interfered on biochemical parameters. The life of cut flowers was significantly increased by treatment with SA irrespective of its concentration, when compared to the control. Therefore, SA an inexpensive that can also natural plant-derived compound has the potential to increase the vase-life of rose cut flowers. Consider SA as a novel substance for commercial applications in the cut rose industry. However, further research is needed to optimize SA treatments for this purpose.

\section{References}

Balestra, G. M., Agostini, R., Bellincontro, A., Mencarelli, F., \& Varvaro, L. (2005). Bacterial populations related to gerbera (Gerbera jamesonii L.) stem break. Phytopathol. Mediterr., 44(3), 1000-1009. https://doi.org/10.1400/14693

Bettiol, W., \& Morandi, M. A. B. (2009). Biocontrole de doenças de plantas: Uso e perspectivas. Embrapa Meio Ambiente (Cap. 6, pp. 85-99). Jaguariúna, SP.

Bradford, M. M. (1976). A rapid and sensitive method for the quantification of microgram quantities of protein utilizing the principle of protein-dye binding. Analitycal Biochemistry, 72, 248-254. https://doi.org/10.1016/ 0003-2697(76)90527-3

Campos, A. D., Ferreira, A. G., Hampe, M. M. V., Antunes, I. F., Brancão, N., Silveira, E. P., ... Osório, V. A. (2003). Induction of chalcone synthase and phenylalanine ammonia-lyase by salicylic acid and Colletotrichum lindemuthianum in common bean. Braz. Plant Physiol., 15(3), 129-134. https://doi.org/ 10.1590/S1677-04202003000300001

Campos, A. D., Ferreira, A. G., Hampe, M. M. V., Antunes, I. F., Brancão, N., Silveira, E. P., ... Augustin, E. (2004). Atividade de peroxidase e polifenoloxidase na resistência do feijão à antracnose. Pesq. Agropec. Bras., 39(7), 637-643. https://doi.org/10.1590/S0100-204X2004000700004

Canakci, S. (2008). Effects of salicylic acid on fresh weight change, chlorophyll and protein amounts of radish (Raphanus sativus L.) seedlings. J. Biol. Sci., 8(2), 431-435. https://doi.org/10.3923/jbs.2008.431.435

Castro, P. R. C., Kluge, R. A., \& Peres, L. E. P. (2005). Manual de fisiologia vegetal: Teoria e prática (p. 650). Piracicaba: Ceres.

Cavalcanti, L. S., Piero, R. M., Cia, P., Paschoalati, S. F., REsende, M. L. V., \& Romeiro, R. S. (2005). Indução de resistência a patógenos e insetos (p. 263). Piracicaba: FEALQ.

Chen, J. Y., Wen, P. F., Kong, W. F., Pan, Q. H., Zhana, J., Lia, J. M., \& Wan, S. B. (2006). Effect of salicylic acid on phenylpropanoids and phenylalanine ammonia-lyase in harvestedgrape grape berries. Postharvest Biology and Technology, 40, 64-72. https://doi.org/10.1016/j.postharvbio.2005.12.017

Chitarra, M. I. F., \& Chitarra, A. B. (2006). Pós-colheita de frutas e hortaliças: Glossário. UFLA, Brazil. 
Cia, P., Pascholati, S. F., \& Benato, E. A. (2007). Indução de resistência no manejo de doenças pós-colheita. In F. Á. Rodrigues, \& R. S. Romeiro (Eds.), Indução de resistência em plantas a patógenos (pp. 245-280). Viçosa: UFV.

Cortes, M. H., Frias, A. A., Moreno, S. G., Piña, M. M., Guzmán, G. H. D. L. C., \& Sandoval, S. G. (2011). The effects of calcium on postharvest water status and vase life of Rosa hybrida cv. 'Grand Gala'. International Journal of Agriculture and Biology, 13(2), 233-238.

Da Silva, R. A., Reis, V. M., Baldani, J. I., \& Olivares, F. L. (2008). Defesa de plantas contra o ataque de fitopatógenos. Embrapa Agrobiologia-Documentos (INFOTECA-E).

Elbe, J. H. von. (2000). Colorantes. In O. W. Fennema (Ed.), Quimica de los alimentos (2nd ed., pp. 782-799). Zaragoza: Wisconsin.

Ezhilmathi, K., Singh, V. P., Arora, A., \& Sairam, R. K. (2007). Effect of 5-sulfosalicylic acid on antioxidant activity in relation to vase life of Gladiolus cut flowers. Plant Growth Regul., 51, 99-108. https://doi.org/10.1007/s10725-006-9142-2

Falker Automação Agrícola Ltda. (2008). Manual do medidor eletrônico de teor clorofila (ClorofiLOG/CFL 1030) (Revisão B, p. 33). Porto Alegre: Falker Automação Agrícola.

Geerdink, G. M. (2012). Efeito de tratamentos de pré e pós-colheita na qualidade de rosas de corte (Dissertação Mestrado, Escola Superior de Agricultura Luiz de Queiroz, Universidade de São Paulo, Piracicaba). https://doi.org/10.11606/D.11.2012.tde-09082012-085941

Hardenburg, R. E., Watada, A. E., \& Wang, C. Y. (1988). Almacenamiento commercial de frutas, legumes y existencias de floriesterias y viveros (pp. 91-121). Costa Rica: IICA.

Hayat, Q., Hayat S., Irfan, M., \& Ahmad, A. (2010). Effect of exogenous salicylic acid under changing environment: A review. Environmental and Experimental Botany, 68(1), 14-25. https://oi.org/10.1016/ j.envexpbot.2009.08.005

Hayat, S., Fariduddin, Q., Ali, B., \& Ahmad, A. (2005). Effect of salicylic acid on growth and enzyme activities of wheat seedlings. Acta Agronomica Hungarica, 53(4), 433-437. https://doi.org/10.1556/AAgr.53.2005.4.9

Karlidag, H., Yildirim, E., \& Metin, T. (2009). Salicylic acid ameliorates the adverse effect of stress on strawberry. Scientia Agricola, 66(2), 180-187. https://doi.org/10.1590/S0103-90162009000200006

Kuhn, O. J. (2007). Indução de resistência em feijoeiro (Phaseolus vulgaris) por acibenzolar-S-metil e Bacillus cereus: Aspectos fisiológicos, bioquímicos e parâmetros de crescimento e produção (p. 140, Tese Doutorado, Escola Superior de Agricultura Luiz de Queiroz, Universidade de São Paulo, Piracicaba).

Leon-Kloosterziel, K. M., Bas, W. M. V., Joost, J. B. K., Jahan, A. V. P., Martijn Rep, L. C., \& Van Loon, C. M. J. P. (2005). Colonization of the Arabidopsis rhizosphere by fluorescent Pseudomonas spp. activates a root-specific, ethylene-responsive PR-5 gene in the vascular bundle. Plant Molecular Biology, 57(5), $731-748$. https://doi.org/10.1007/s11103-005-3097-y

Matsuno, H., \& Uritani, I. (1972). Physiological behavior of peroxidase isozymes in sweet potato root tissue injured by cutting or with black rot. Plant and Cell Physiology, 23, 1091-1101.

Pascholati, S. F., \& Leite, B. (1995). Hospedeiro: Mecanismos de resistência. In A. Bergamin Filho, H. Kimati, \& L. Amorin (Eds.), Manual de fitopatologia: Princípios e conceitos (3rd ed., Vol. 1, pp. 417-453). São Paulo-SP: Agronômica Ceres.

Raskin, I. (1992). Role of salicylic acid in plants. Annual Review of Plant Physiology and Plant Molecular Biology, 43, 439-463. https://doi.org/10.1146/annurev.pp.43.060192.002255

Resende, M. L. V., Salgado, S. M. L., \& Chaves, Z. M. (2003). Espécies ativas de oxigênio na resposta de defesa de planta a patógenos. Fitopatologia Brasileira, 28(2). https://doi.org/10.1590/S0100-41582003000200001

Rossarolla, M. D., Tomazetti, T. C., Copatti, A. S., Monteiro, A. M., Righi, P. S., \& Aguila, J. S. (2012). Estudo da aplicação de ácido salicílico na pré-colheita em laranja 'Salustiana' (pp. 1737-1740). XXII Congresso Brasileiro de Fruticultura. Bento Gonçalves, RS.

Shakib, M. F., Naderib, R., \& Boojarc, M. M. A. (2012). Effect of salicylic acid application on morphological, physiological and biochemical characteristics of Cyclamen persicum Miller. Annals of Biological Research. Retrieved November 3, 2013, from http://scholarsresearchlibrary.com/ABR-vol3-iss12/ABR-2012-3-125631-5639.pdf 
Silva, F. A. S., \& Azevedo, C. A. V. (2009). Principal Components Analysis in the Software Assistat-Statistical Attendance. World Congress on Computers in Agriculture, 7. Reno-NV-USA: American Society of Agricultural and Biological Engineers.

Silva, R. A., Reis, V. M., Baldani, J. I., \& Olivares, F. L. (2008). Defesa contra o ataque de patógenos. Documentos Embrapa Agrobiologia (p. 49). Seropédica, RJ.

Spletzer, M. E., \& Enyedi, A. J. (1999). Salicylic acid induces resistance to Alternaria solani in hydroponically grown tomato. Phytopathology, 89, 22-727. https://doi.org/10.1094/PHYTO.1999.89.9.722

Zamani, S., Kazemi, M., \& Aran, M., (2011). Postharvest Life of Cut Rose Flowers as Affected by Salicylic Acid and Glutamin. World Applied Sciences Journal, 12(9), 1621-1624. Retrieved September 15, 2013, from http://www.idosi.org/wasj/wasj12(9)/38.pdf

Zhang, Y., Chen, K., Zhang, S., \& Ferguson, I. (2003). The role of salicylic acid in postharvest ripening of kiwifruit. Postharvest Biology and Technology, 28, 64-74. https://doi.org/10.1016/S0925-5214(02)00172-2

\section{Copyrights}

Copyright for this article is retained by the author (s), with first publication rights granted to the journal.

This is an open-access article distributed under the terms and conditions of the Creative Commons Attribution license (http://creativecommons.org/licenses/by/4.0/). 